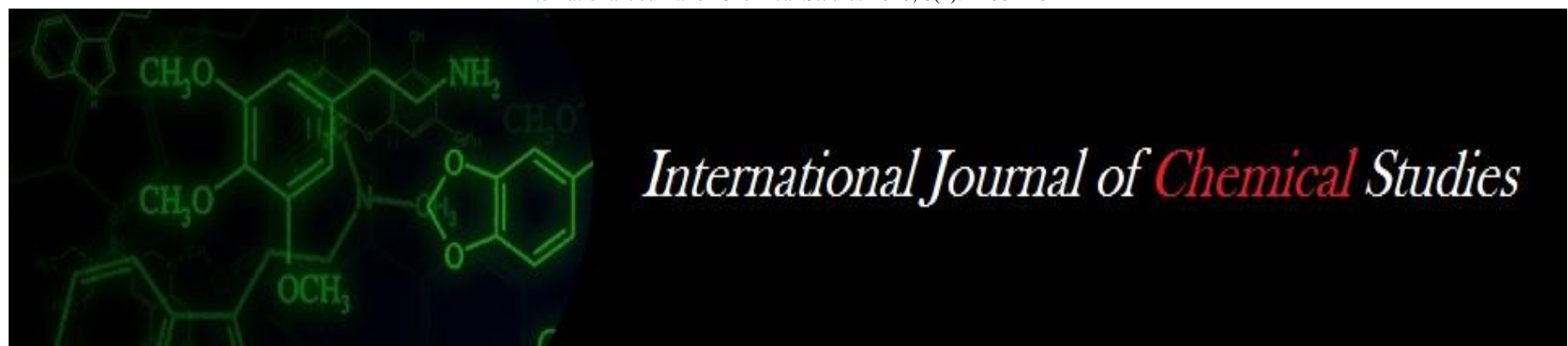

P-ISSN: 2349-8528

E-ISSN: 2321-4902

IJCS 2020; 8(1): 1100-1104

(C) 2020 IJCS

Received: 01-11-2019

Accepted: 05-12-2019

Shobha Talawar

Department of Soil Science and Agricultural Chemistry, College of Agriculture, Shivamogga, Karnataka, India

Dhananjaya BC

University of Agricultural and

Horticultural Sciences,

Shivamogga, Karnataka, India

Corresponding Author:

Shobha Talawar

Department of Soil Science and Agricultural Chemistry, College of Agriculture, Shivamogga,

Karnataka, India

\section{Effect of different levels of phosphorus and phosphorus solubilizers on phosphorus fractions in soil at different stages of paddy}

\section{Shobha Talawar and Dhananjaya BC}

\author{
DOI: $\underline{\text { https://doi.org/10.22271/chemi.2020.v8.i1o.8396 }}$
}

\begin{abstract}
In order to know the effect of $\mathrm{P}$ levels and $\mathrm{P}$ solubilizers on $\mathrm{P}$ fractions in soil at different growth stages of Paddy a field experiment was conducted at Agricultural and Horticultural Research station Bavikere, during kharif seasion in 2017-18. The levels of phosphorus at 0, 50, 75 and $100 \% \mathrm{P}_{2} \mathrm{O}_{5}$ as per ha ${ }^{-1}$ with and without $\mathrm{P}$ solubilizer seedling treatment were tried in a randomized complete block design (RCBD) with twelve treatments and three replication. At different growth stages higher valves of Saloid $-\mathrm{P}$ and $\mathrm{Ca}-\mathrm{P}$ and available $\mathrm{P}$ status in soil were recorded in treatment received recommended NPK with PSF seedling treatment. Higher values of $\mathrm{Al}-\mathrm{P}, \mathrm{Fe}-\mathrm{P}$, red $-\mathrm{P}$, occl $-\mathrm{P}$, organic $-\mathrm{P}$ and total $-\mathrm{P}$ fractions were recorded in treatments recieved only $\mathrm{P}$ levels without $\mathrm{P}$ solubilizers seedling treatment compared to the application of $\mathrm{P}$ levels with $\mathrm{P}$ solubilizers seedling treatment.
\end{abstract}

Keywords: Phosphorus, paddy, available P, PSF, PSB

\section{Introduction}

Phosphorus is known to play an important physiological and bio-chemical role in crop plants. Therefore, it regulates the crop growth and yield to the greater extent. A recent estimate revealed that 49.3 per cent of cultivated lands are deficient in available phosphorus. The added fertilizer phosphorus gets fixed in soil and it is not available to the crops. Therefore, primary approach in agronomic management of phosphorus is to scavenge the native/fixed phosphorus and also to overcome the fixation of applied P-fertilizer. The low cost practice to activate this objective is to inoculate soil with the phosphorus solubilizing fungi and bacteria. Many types of microorganisms are known to inhabit soil, especially rhizosphere and play an important role in plant growth and development. (Gerretsen 1948) ${ }^{[5]}$, initially demonstrated that microbiological activity in the rhizosphere could dissolve sparingly soluble inorganic $\mathrm{P}$ and increase plant growth. Phosphorus in different forms might be taken up by the plants, but by far, the major form absorbed either is HPO4 2- or H2 PO4 - (Beever and Burns, 1981) ${ }^{[1]}$. Several soil fungi and bacteria particularly those belonging to the genera Penicillium, Aspergillus and Pseudomonas possess ability to bring insoluble soil phosphates into soluble forms by secreting weak organic acids such as formic, acetic, propionic, lactic, glucolic, fumaric and succinic. There is lack of information on the use of phosphorus solubilizer microorganism under paddy soil. Therefore, a field experiment was conducted to assess the role of $\mathrm{P}$ solubilizers in phosphorus solubilization and phosphorus content in paddy in soils of submergence to determine the Effect of different levels of Phosphrous and P solubilizers on $\mathrm{P}$ fractions in soil at different stages of paddy.

\section{Materials and Methods}

Field experiment was conducted at Agricultural and Horticultural Research station Bavikere, during the year 2017-18. The different levels of phosphorus at 0, 50, 75 and 100\% P2O5 as DAP per ha-1 with and without $\mathrm{P}$ solubilizer seedling treatment were tried in a randomized complete block design (RCBD) with three replication and twelve treatments. Soil samples were collected from Ap horizon (0-15 depth) at different growth stages of crop growth like 30, 60, 90 days after planting and at harvest of the crop. The soil samples are air dried at room temperature. The initial soils have sandy clay loam in texture with $\mathrm{pH}$ of 5.98 with an organic carbon content of (5.32 g kg-1). Further, the soil was low in nitrogen (236.43 kg ha-1), high in 
phosphorus status (89.51 kg ha-1) and medium in available potassium status (193.32 kg ha-1). The experiment consists of twelve treatments with replicated three times and laid out in a randomized complete block design with different levels of $\mathrm{P}$ solubilizers and P levels. The treatments include T1. RDF NK only T2. RDF NK + PSB T3. RDF NK + PSF T4. RDF NK + $50 \%$ RDP T5. RDF NK $+50 \%$ of RDP + PSB T6. RDF NK + $50 \%$ of RDP + PSF T7. RDF NK $+75 \%$ of RDP T8. RDF $\mathrm{NK}+75 \%$ of RDP + PSB T9. RDF NK $+75 \%$ of RDP + PSF T10. RDF NPK T11. RDF NPK + PSB. T12. RDF NPK + PSF and 10 tons FYM was common for all the treatments including control Total phosphorus in the soils was estimated by digesting one gram of finely powdered soil with perchloric acid as outlined by Jackson (1967) ${ }^{[7]}$. Inorganic phosphate fractions viz., Saloid $-\mathrm{P}, \mathrm{Al}-\mathrm{P}, \mathrm{Fe}-\mathrm{P}$, Red $-\mathrm{P}$, Occl $-\mathrm{P}$ and $\mathrm{Ca}-\mathrm{P}$ by the fractionation procedure of Peterson and Corey (1966). Organic phosphorus content in soil was calculated as the difference between the total $\mathrm{P}$ content and the total mineral P content of soil. The data collected was analysed statistically following the procedure as described by Gomez and Gomez (1984). The level of significance used in ' $F$ ' and ' $t$ ' test was $\mathrm{P}=0.05$. Critical differences were calculated wherever ' $F$ ' test was significant.

\section{Result and Discussion}

Higher values of saloid: $\mathrm{P}$ fractions were recorded in treatments received $\mathrm{P}$ levels with $\mathrm{P}$ solubilizers seedling treatment compared to the application of only $\mathrm{P}$ levels. Treatment $\mathrm{T} 12$ receiving recommended NPK with PSF seedling treatment recorded significantly higher saloid - P fraction in soil $(22.71,25.78,29.26$, and $34.77 \mathrm{mg} \mathrm{kg}-1$ at 30 , 60,90 DAP and at harvest, respectively) followed by treatment T11 receving recommended NPK with PSB seedling treatment $(21.69 \mathrm{mg} \mathrm{kg}-1)$ compared to other treatments(Table 1). Because they attributed it to complexing of $\mathrm{P}$ fixing metallic cations with organic acids released from $\mathrm{P}$ solubilizing micro-organisms and preventing $\mathrm{P}$ to be adsorbed on soil particles. Thus, it helped in extraction of loosely bonded $\mathrm{NH} 4 \mathrm{Cl}$ extractable fraction of $\mathrm{P}$. These results are agreement with the findings of Singaram and Kothandaraman (1993) ${ }^{[17]}$ also observed that application of P irrespective of the sources tended to increase the content of saloid - P. higher amount of saloid - P in soil was observed with water soluble P source. Incorporation of PSB with DAP and rock phosphate (RP) marginally increased saloid - $\mathrm{P}$ value compared to RP and DAP alone. (Singaram and Kothandaraman 1992) ${ }^{[16] .}$

Table 1: Effect of $\mathrm{P}$ levels and $\mathrm{P}$ solubilizers seedling treatment on Saloid $\mathrm{P}$ and Aluminium $\mathrm{P}$ fractions in soil at different intervals in paddy

\begin{tabular}{|c|c|c|c|c|c|c|c|c|}
\hline \multirow{2}{*}{ Treatments } & \multicolumn{4}{|c|}{ Saloid:P (mg kg-1) } & \multicolumn{4}{|c|}{ Aluminium: $\mathbf{P}\left(\mathrm{mg} \mathrm{kg}^{-1}\right)$} \\
\hline & \begin{tabular}{|l|} 
30 DAP \\
\end{tabular} & 60 DAP & \begin{tabular}{|l|} 
90 DAP \\
\end{tabular} & Harvest & 30 DAP & 60 DAP & 90 DAP & Harvest \\
\hline $\mathrm{T}_{1}$ : Recommended NK only & $9.78(3.0)$ & $\begin{array}{c}13.90 \\
(4.3)\end{array}$ & $\begin{array}{c}18.10 \\
(5.6)\end{array}$ & $\begin{array}{c}18.88 \\
(6.5)\end{array}$ & $\begin{array}{c}30.44 \\
(10.2)\end{array}$ & $\begin{array}{l}33.45 \\
(10.3)\end{array}$ & $\begin{array}{c}31.01 \\
(9.6)\end{array}$ & $\begin{array}{c}30.29 \\
(3.0)\end{array}$ \\
\hline $\mathrm{T}_{2}:$ Recommended NK + PSB & $\begin{array}{l}11.55 \\
(3.6)\end{array}$ & $\begin{array}{l}15.00 \\
(4.8)\end{array}$ & $\begin{array}{c}19.80 \\
(6.8)\end{array}$ & $\begin{array}{c}20.20 \\
(7.0)\end{array}$ & $26.71(9.1)$ & $29.01(9.3)$ & $\begin{array}{r}27.77 \\
(9.5)\end{array}$ & $\begin{array}{l}26.83 \\
(3.6)\end{array}$ \\
\hline $\mathrm{T}_{3}:$ Recommended NK + PSF & $\begin{array}{l}12.62 \\
(4.0)\end{array}$ & $\begin{array}{r}15.89 \\
(5.3)\end{array}$ & $\begin{array}{l}19.52 \\
(6.9)\end{array}$ & $\begin{array}{c}22.64 \\
(8.1)\end{array}$ & $25.38(9.4)$ & $\begin{array}{l}28.70 \\
(10.0)\end{array}$ & $\begin{array}{l}27.13 \\
(9.6)\end{array}$ & $\begin{array}{l}26.62 \\
(4.0)\end{array}$ \\
\hline $\mathrm{T}_{4}:$ Recommended NK $+50 \%$ Recommended $\mathrm{P}$ & $\begin{array}{l}12.57 \\
(3.7)\end{array}$ & $\begin{array}{l}16.06 \\
(4.6)\end{array}$ & $\begin{array}{c}19.56 \\
(5.1)\end{array}$ & $\begin{array}{c}22.71 \\
(5.6)\end{array}$ & $\begin{array}{l}33.37 \\
(10.3)\end{array}$ & $\begin{array}{l}35.45 \\
(10.2) \\
\end{array}$ & $\begin{array}{c}33.26 \\
(8.6)\end{array}$ & $\begin{array}{l}35.64 \\
(3.7)\end{array}$ \\
\hline $\begin{array}{c}\text { T5: Recommended NK }+50 \% \text { Recommended P + } \\
\text { PSB }\end{array}$ & $\begin{array}{l}15.40 \\
(4.8)\end{array}$ & $\begin{array}{l}18.41 \\
(5.7)\end{array}$ & $21.746 .1)$ & $\begin{array}{c}24.13 \\
(6.5) \\
\end{array}$ & $\begin{array}{l}27.94 \\
(10.3)\end{array}$ & $\begin{array}{r}32.84 \\
(10.2) \\
\end{array}$ & $\begin{array}{l}30.49 \\
(8.6)\end{array}$ & $\begin{array}{l}31.50 \\
(4.8)\end{array}$ \\
\hline $\begin{array}{c}\mathrm{T}_{6}: \text { Recommended NK }+50 \% \text { Recommended P }+ \\
\text { PSF }\end{array}$ & $\begin{array}{c}16.06 \\
(5.1)\end{array}$ & $\begin{array}{l}19.06 \\
(5.9)\end{array}$ & $\begin{array}{c}22.06 \\
(6.3)\end{array}$ & $\begin{array}{c}25.46 \\
(7.0)\end{array}$ & $27.26(9.9)$ & $31.55(9.8)$ & $\begin{array}{l}31.66 \\
(9.0)\end{array}$ & $\begin{array}{l}30.31 \\
(5.1)\end{array}$ \\
\hline $\mathrm{T}_{7}:$ Recommended NK $+75 \%$ Recommended $\mathrm{P}$ & $\begin{array}{l}16.80 \\
(4.8)\end{array}$ & $\begin{array}{c}20.25 \\
(5.4)\end{array}$ & $\begin{array}{c}24.16 \\
(6.0)\end{array}$ & $\begin{array}{c}26.06 \\
(6.2)\end{array}$ & $\begin{array}{l}38.31 \\
(12.3) \\
\end{array}$ & $\begin{array}{l}42.87 \\
(11.5)\end{array}$ & $\begin{array}{c}36.41 \\
(9.1)\end{array}$ & $\begin{array}{l}38.95 \\
(4.8)\end{array}$ \\
\hline $\begin{array}{c}\text { T8: Recommended NK + } 75 \% \text { Recommended P } \\
+ \text { PSB }\end{array}$ & $\begin{array}{c}18.81 \\
(5.6)\end{array}$ & $\begin{array}{r}22.65 \\
(6.8)\end{array}$ & $\begin{array}{c}26.40 \\
(7.1)\end{array}$ & $\begin{array}{c}28.40 \\
(7.1)\end{array}$ & $\begin{array}{l}35.35 \\
(11.0)\end{array}$ & $\begin{array}{l}37.28 \\
(11.1)\end{array}$ & $\begin{array}{l}33.05 \\
(8.9)\end{array}$ & $\begin{array}{l}34.95 \\
(5.6)\end{array}$ \\
\hline $\begin{array}{c}\mathrm{T}_{9}: \text { Recommended NK }+75 \% \text { Recommended P } \\
+\mathrm{PSF}\end{array}$ & $\begin{array}{l}19.96 \\
(6.0)\end{array}$ & $\begin{array}{c}23.78 \\
(7.4) \\
\end{array}$ & $\begin{array}{c}26.98 \\
(7.4) \\
\end{array}$ & $\begin{array}{l}29.62 \\
(7.5) \\
\end{array}$ & $\begin{array}{l}35.07 \\
(11.1)\end{array}$ & $\begin{array}{l}36.83 \\
(11.4) \\
\end{array}$ & $\begin{array}{l}32.22 \\
(8.9)\end{array}$ & $\begin{array}{c}34.12 \\
(6.0)\end{array}$ \\
\hline $\mathrm{T}_{10}:$ Recommended NPK & $\begin{array}{c}20.54 \\
(5.6)\end{array}$ & $\begin{array}{c}23.98 \\
(5.9)\end{array}$ & $\begin{array}{r}27.65 \\
(6.4)\end{array}$ & $\begin{array}{l}30.11 \\
(6.7)\end{array}$ & $\begin{array}{l}43.31 \\
(12.7)\end{array}$ & $\begin{array}{l}46.00 \\
(11.3)\end{array}$ & $\begin{array}{l}40.04 \\
(9.3)\end{array}$ & $\begin{array}{c}43.15 \\
(5.6)\end{array}$ \\
\hline $\mathrm{T}_{11}:$ Recommended NPK + PSB & $\begin{array}{c}21.69 \\
(6.3)\end{array}$ & $\begin{array}{c}24.61 \\
(6.6)\end{array}$ & $\begin{array}{l}28.24 \\
(7.4)\end{array}$ & $\begin{array}{c}33.43 \\
(7.9)\end{array}$ & $39.3611 .6)$ & $\begin{array}{l}40.29 \\
(10.8)\end{array}$ & $\begin{array}{c}37.31 \\
(9.8)\end{array}$ & $\begin{array}{c}40.19 \\
(6.3)\end{array}$ \\
\hline $\mathrm{T}_{12}:$ Recommended NPK + PSF & $\begin{array}{c}22.71 \\
(6.7)\end{array}$ & $\begin{array}{c}25.78 \\
(7.2)\end{array}$ & $\begin{array}{c}29.26 \\
(7.7)\end{array}$ & $\begin{array}{c}34.77 \\
(8.2)\end{array}$ & $\begin{array}{l}37.98 \\
(11.5)\end{array}$ & $\begin{array}{l}38.98 \\
(10.8)\end{array}$ & $\begin{array}{c}36.81 \\
(9.6)\end{array}$ & $\begin{array}{l}39.04 \\
(9.2)\end{array}$ \\
\hline S. Em. \pm & 0.58 & 0.56 & 0.48 & 0.39 & 1.06 & 1.41 & 1.07 & 0.81 \\
\hline C.D. $(p=0.05)$ & 1.70 & 1.64 & 1.41 & 1.14 & 3.10 & 4.15 & 3.13 & 2.37 \\
\hline
\end{tabular}

Note: FYM is common to all the treatments PSB: Phosphorus Solubilizing Bacteria PSF: Phosphorus Solubilizing Fungi DAP - Days after planting. Figures in the parenthesis indicate the per cent contribution to the total P pool.

Higher values of Al: $\mathrm{P}$ fractions were recorded in treatments received only $\mathrm{P}$ levels without $\mathrm{P}$ solubilizers seedling treatment compared to the application of $\mathrm{P}$ levels with $\mathrm{P}$ solubilizers seedling treatment. Highest $\mathrm{Al}-\mathrm{P}$ fractions values was recorded in treatment that received recommended NPK (T10) (43.31, 46.00, 40.04 and $43.15 \mathrm{mg} \mathrm{kg}-1$, at 30, 60, 90 DAP and at harvest, respectively) followed by treatment that received $75 \%$ recommended P2O5 ha-1 as DAP with and without $\mathrm{P}$ solubilizers seedling treatment (T8 and T9) compare to other treatment (Table1). This may be due to application of $\mathrm{P}$ fertilizers which increased the Al-P content over control. This suggests that portion of added $\mathrm{P}$ was transformed into $\mathrm{Al}$ - P. Treatments comprising application of water soluble $\mathrm{P}$ sources like DAP, favoured greater formation and accumulation of $\mathrm{Al}-\mathrm{P}$ content of soil. This may be attributed to dissolution of aluminium of the clay in the acid produced as a result of hydrolysis of DAP in soil. It corroborates with the findings of Rao et al., (1972) and Sheela (2006) ${ }^{[14]}$.

Higher values of Fe: $\mathrm{P}$ fractions was recorded in treatments received $\mathrm{P}$ levels only compared to $\mathrm{P}$ levels with PSB seed 
treatment. Highest values of $\mathrm{Fe}-\mathrm{P}$ fraction was recorded in treatment that received recommended NPK (T10) (44.50, $52.93,53.64$ and $55.53 \mathrm{mg} \mathrm{kg}-1$ at 30, 60, 90 DAP and at harvest, respectively) followed by treatment that received RDF with PSB seedling treatment. Compare to other treatments. (Table 2) There is no significant variation in the values of Fe - P fraction at different stages of crop growth. Application of DAP resulted in the formation of more $\mathrm{Fe}-\mathrm{P}$ during different period of incubation in the soil as the soluble monocalcium phosphate of DAP would have been converted to Fe - P and Al - P (Singh and Singh, 1976) ${ }^{[18]}$. Chang and Jackson (1957) ${ }^{[2]}$ and Yuan et al., (1960) ${ }^{[19]}$ they also observed that application of phosphatic fertilizers to acid soils increases the fixation and transformation of added phosphate into $\mathrm{Fe}-\mathrm{P}$. The reduction of $\mathrm{Fe}-\mathrm{P}$ with $\mathrm{P}$ - solubilizers compared to phosphate fertilizers alone is ascribed to dissolution of iron oxide coatings with organic acids produced by $\mathrm{P}$ solubilizers causing reduction in $\mathrm{Fe}-\mathrm{P}$. And these results corroborate with the findings of Sheela (2006) ${ }^{[14]}$.

Table 2: Effect of $\mathrm{P}$ levels and $\mathrm{P}$ solubilizers seedling treatment on iron $\mathrm{P}$ and reductant soluble $\mathrm{P}$ fractions in soil at different intervals in paddy

\begin{tabular}{|c|c|c|c|c|c|c|c|c|}
\hline \multirow{2}{*}{ Treatments } & \multicolumn{4}{|c|}{ Iron:P $\left(\mathrm{mg} \mathrm{kg}^{-1}\right)$} & \multicolumn{4}{|c|}{ Reductant soluble: $\mathbf{P}\left(\mathrm{mg} \mathrm{kg}^{-1}\right)$} \\
\hline & 30 DAP & 60 DAP & 90 DAP & Harvest & 30 DAP & 60 DAP & 90 DAP & Harvest \\
\hline $\mathrm{T}_{1}$ : Recommended NK only & $\begin{array}{l}35.86 \\
(10.9)\end{array}$ & $37.35(11.5)$ & $\begin{array}{l}39.35 \\
(12.2)\end{array}$ & $\begin{array}{l}42.35 \\
(14.5)\end{array}$ & $\begin{array}{l}47.88 \\
(14.6)\end{array}$ & $\begin{array}{l}43.60 \\
(12.0)\end{array}$ & $\begin{array}{l}38.78 \\
(12.1)\end{array}$ & $38.78(13.3)$ \\
\hline $\mathrm{T}_{2}:$ Recommended NK + PSB & $\begin{array}{l}33.83 \\
(10.6)\end{array}$ & $34.63(11.1)$ & $\begin{array}{l}35.52 \\
(12.2)\end{array}$ & $\begin{array}{l}34.85 \\
(12.1)\end{array}$ & $\begin{array}{l}42.60 \\
(13.4)\end{array}$ & $\begin{array}{l}37.51 \\
(10.8)\end{array}$ & $\begin{array}{l}33.85 \\
(11.6)\end{array}$ & $33.17(11.5)$ \\
\hline $\mathrm{T}_{3}:$ Recommended NK + PSF & $\begin{array}{l}33.93 \\
(10.7)\end{array}$ & $33.93(11.4)$ & $\begin{array}{l}34.98 \\
(12.4)\end{array}$ & $\begin{array}{l}33.88 \\
(12.1)\end{array}$ & $\begin{array}{l}41.42 \\
(13.1)\end{array}$ & $\begin{array}{l}35.98 \\
(11.0)\end{array}$ & $\begin{array}{l}32.63 \\
(11.6)\end{array}$ & $32.62(11.6)$ \\
\hline $\mathrm{T}_{4}$ : Recommended NK $+50 \%$ Recommended $\mathrm{P}$ & $\begin{array}{l}38.47 \\
(11.2)\end{array}$ & $42.94(12.3)$ & $\begin{array}{l}43.32 \\
(11.2)\end{array}$ & $\begin{array}{l}45.55 \\
(11.3)\end{array}$ & $\begin{array}{l}61.30 \\
(17.8)\end{array}$ & $\begin{array}{l}55.14 \\
(14.4)\end{array}$ & $\begin{array}{l}50.23 \\
(13.0)\end{array}$ & $51.90(12.9)$ \\
\hline $\begin{array}{c}\text { T5: Recommended NK + } 50 \% \text { Recommended P } \\
+ \text { PSB }\end{array}$ & $\begin{array}{l}35.07 \\
(11.0)\end{array}$ & $\begin{array}{c}35.90 \\
(11.10)\end{array}$ & $\begin{array}{l}38.88 \\
(10.9)\end{array}$ & $\begin{array}{l}38.54 \\
(10.4)\end{array}$ & $\begin{array}{l}55.89 \\
(17.5)\end{array}$ & $\begin{array}{l}51.63 \\
(13.9)\end{array}$ & $\begin{array}{l}44.96 \\
(12.6)\end{array}$ & $44.28(12.0)$ \\
\hline $\begin{array}{c}\mathrm{T}_{6}: \text { Recommended } \mathrm{NK}+50 \% \text { Recommended } \mathrm{P} \\
+\mathrm{PSF}\end{array}$ & $\begin{array}{c}33.51 \\
(10.5)\end{array}$ & $35.35(10.9)$ & $\begin{array}{c}37.93 \\
(10.8)\end{array}$ & $\begin{array}{c}36.77 \\
(10.10\end{array}$ & $\begin{array}{l}53.67 \\
(16.9)\end{array}$ & & $\begin{array}{l}43.58 \\
(12.4)\end{array}$ & $\begin{array}{c}42.24 \\
(10.50)\end{array}$ \\
\hline $\mathrm{T}_{7}:$ Recommended NK $+75 \%$ Recommended $\mathrm{P}$ & $\begin{array}{l}41.82 \\
(12.0)\end{array}$ & $45.22(12.1)$ & $\begin{array}{l}46.94 \\
(11.7)\end{array}$ & $\begin{array}{l}49.11 \\
(11.60\end{array}$ & $\begin{array}{l}65.66 \\
(18.9)\end{array}$ & $\begin{array}{l}58.36 \\
15.2)\end{array}$ & $\begin{array}{l}56.80 \\
(14.2)\end{array}$ & $52.24(12.0)$ \\
\hline $\begin{array}{c}\mathrm{T}_{8}: \text { Recommended NK }+75 \% \text { Recommended P } \\
+\mathrm{PSB}\end{array}$ & $\begin{array}{c}36.50 \\
(10.8)\end{array}$ & $41.84(12.5)$ & $\begin{array}{l}42.83 \\
(11.6)\end{array}$ & $44.1(11.1)$ & $\begin{array}{l}63.49 \\
(18.8)\end{array}$ & $\begin{array}{l}53.74 \\
(14.3)\end{array}$ & $\begin{array}{l}48.08 \\
(13.0)\end{array}$ & $45.89(10.8)$ \\
\hline $\begin{array}{c}\mathrm{T}_{9}: \text { Recommended } \mathrm{NK}+75 \% \text { Recommended } \mathrm{P} \\
+\mathrm{PSF}\end{array}$ & $\begin{array}{c}35.87 \\
(10.8)\end{array}$ & $41.76(12.9)$ & $\begin{array}{l}42.09 \\
(11.6)\end{array}$ & $\begin{array}{l}43.53 \\
(11.0)\end{array}$ & $\begin{array}{l}62.67 \\
(18.9)\end{array}$ & $\begin{array}{l}52.85 \\
(14.7)\end{array}$ & $\begin{array}{l}47.67 \\
(13.1)\end{array}$ & $45.68(10.8)$ \\
\hline T10: Recommended NPK & $\begin{array}{l}44.93 \\
(12.4)\end{array}$ & $50.52(12.5)$ & $\begin{array}{l}53.64 \\
(12.5)\end{array}$ & $\begin{array}{c}55.53 \\
(12.4)\end{array}$ & $\begin{array}{l}71.90 \\
(19.8)\end{array}$ & $\begin{array}{l}64.21 \\
(15.0)\end{array}$ & $\begin{array}{c}60.84 \\
(14.2)\end{array}$ & $58.50(12.4)$ \\
\hline $\mathrm{T}_{11}$ : Recommended NPK + PSB & $\begin{array}{l}41.76 \\
(12.0)\end{array}$ & 46.94 (12.6) & $\begin{array}{l}47.50 \\
(12.5)\end{array}$ & $\begin{array}{l}48.39 \\
(11.4)\end{array}$ & $\begin{array}{l}65.73 \\
(18.9)\end{array}$ & $\begin{array}{l}57.72 \\
(14.5)\end{array}$ & $\begin{array}{l}54.06 \\
(14.2)\end{array}$ & 53.38 12.0) \\
\hline $\mathrm{T}_{12}:$ Recommended NPK + PSF & $\begin{array}{l}40.63 \\
(12.0) \\
\end{array}$ & $44.94(12.5)$ & $\begin{array}{l}46.76 \\
(12.3) \\
\end{array}$ & $\begin{array}{l}46.81 \\
(11.1) \\
\end{array}$ & $\begin{array}{l}64.04 \\
(18.9) \\
\end{array}$ & $\begin{array}{c}57.00 \\
(14.5) \\
\end{array}$ & $\begin{array}{l}52.40 \\
(13.7) \\
\end{array}$ & $52.18(12.4)$ \\
\hline S. Em. \pm & 1.06 & 1.31 & 1.11 & 1.68 & 1.17 & 1.47 & 1.60 & 1.45 \\
\hline C.D. $(p=0.05)$ & 3.12 & 3.85 & 3.26 & 4.91 & 3.43 & 4.31 & 4.68 & 4.24 \\
\hline
\end{tabular}

Note: FYM is common to all the treatments PSB: Phosphorus Solubilizing Bacteria PSF: Phosphorus Solubilizing Fungi DAP - Days after planting. Figures in the parenthesis indicate the per cent contribution to the total P pool.

Higher values of red soluble - $\mathrm{P}$ fractions was recorded in treatments received only $\mathrm{P}$ levels compared to $\mathrm{P}$ levels with PSB seed treatment. Highest values of red soluble - P fraction was recorded in treatment that received recommended NPK (71.90, 64.21, 60.84 and $58.50 \mathrm{mg} \mathrm{kg-1}$ at 30, 60, 90 DAP and at harvest, respectively) followed treatment that received recommended NPK with PSB seedling treatment. Compare to other treatments (Table 2). The lowest value of Red - P fraction in soil was recorded in treatment that received recommended NK with PSF seedling treatment. This may be due to addition of $\mathrm{P}$ fertilizers significantly increased the fixation and transformation of added $\mathrm{P}$ in the soil. Application of DAP resulted in higher buildup of red soluble $-\mathrm{P}$ values compared to other treatments. Since, DAP is water soluble, readily reacts with ferric hydroxides, leading to conversion of water soluble form to insoluble form (Singaram and Kothandaraman, 1991) ${ }^{[15]}$. The reduction of red soluble - P with $\mathrm{P}$ - solubilizers compared to $\mathrm{P}$ fertilizers alone is attributed to dissolution of iron oxide coatings with organic acids produced by $\mathrm{P}$ solubilizers. These results are in agreement with the findings of Sheela (2006) ${ }^{[14]}$. Higher values of occluded - $\mathrm{P}$ fractions were recorded in treatments received $\mathrm{P}$ levels only compared to $\mathrm{P}$ levels with $\mathrm{P}$ solubilizers seedling treatment Highest values of occluded - P fraction was recorded in treatment that received recommended NPK $(27.84,23.50,27.50$, and $17.53 \mathrm{mg} \mathrm{kg-1}$ at 30,60, 90 DAP and at harvest, respectively) followed treatment that received recommended NPK with PSB seedling treatment. Compare to other treatments (Table 3). The fixation and transformation of native and added $\mathrm{P}$ to occl $-\mathrm{P}$ is generally low (Ranjit, 2005) ${ }^{[12]}$. Treatments involving application of $\mathrm{P}$ solubilizers recorded lower occl - $\mathrm{P}$ values. This might be due to dissolution of $\mathrm{Al}-\mathrm{P}$ and $\mathrm{Fe}-\mathrm{P}$ present in the form of oxides of $\mathrm{Fe}$ and $\mathrm{Al}$ by the action of organic acids released by $\mathrm{P}$ solubilizers and these results are in accordance with the findings of Goroji (2000) ${ }^{[6]}$. 
Table 3: Effect of $P$ levels and $P$ solubilizers seedling treatment occluded $P$ and calcium $P$ fractions in soil at different intervals in paddy

\begin{tabular}{|c|c|c|c|c|c|c|c|c|}
\hline \multirow{2}{*}{ Treatments } & \multicolumn{4}{|c|}{ Occluded: $\mathbf{P}\left(\mathrm{mg} \mathrm{kg}^{-1}\right)$} & \multicolumn{4}{|c|}{ Calcium: $\mathbf{P}\left(\mathrm{mg} \mathrm{kg}^{-1}\right)$} \\
\hline & 30 DAP & 60 DAP & 90 DAP & Harvest & 30 DAP & 60 DAP & 90 DAP & Harvest \\
\hline $\mathrm{T}_{1}$ : Recommended NK only & $19.51(5.9)$ & $15.52(4.8)$ & $20.18(5.7)$ & $10.14(3.5)$ & $5.4(1.8)$ & $5.43(1.8)$ & $4.98(1.5)$ & $3.17(1.1)$ \\
\hline $\mathrm{T}_{2}$ : Recommended NK + PSB & $16.49(5.2)$ & $12.50(4.0)$ & $17.15(6.2)$ & $8.95(3.1)$ & $5.63(1.8)$ & $5.63(1.8)$ & $5.13(1.8)$ & $4.14(1.4)$ \\
\hline $\mathrm{T}_{3}:$ Recommended NK + PSF & $15.47(4.9)$ & $11.75(4.0)$ & $15.80(6.10$ & $8.83(3.2)$ & $6.57(2.0)$ & $6.07(1.9)$ & $5.63(2.0)$ & $4.30(1.5)$ \\
\hline $\mathrm{T}_{4}:$ Recommended NK + $50 \%$ Recommended P & 21.14(6.1) & $18.66(5.3)$ & $21.80(5.3)$ & $12.32(3.1)$ & $7.23(2.4)$ & $6.37(2.3)$ & $6.53(1.7)$ & $4.70(1.2)$ \\
\hline T5: Recommended NK + $50 \%$ Recommended P + PSB & $18.74(5.9)$ & $15.81(4.9)$ & $19.41(5.8)$ & $9.92(2.7)$ & $7.53(2.4)$ & $6.9(2.1)$ & $6.87(1.9)$ & $5.87(1.6)$ \\
\hline $\mathrm{T}_{6}:$ Recommended NK + $50 \%$ Recommended P + PSF & $17.93(5.6)$ & $14.87(4.6)$ & $18.60(5.8)$ & $9.56(2.6)$ & $8.1(2.3)$ & $7.25(2.0)$ & $7.19(2.0)$ & $5.99(1.6)$ \\
\hline $\mathrm{T}_{7}:$ Recommended NK $+75 \%$ Recommended $\mathrm{P}$ & $24.28(7.0)$ & $21.54(5.8)$ & $24.95(5.9)$ & $14.20(3.4)$ & $8.13(2.7)$ & $7.43(2.2)$ & $7.90(2.0)$ & $6.81(1.6)$ \\
\hline T8: Recommended NK + $75 \%$ Recommended P +PSB & $21.18(6.3)$ & $18.82(5.6)$ & $21.84(5.9)$ & $12.83(3.2)$ & $8.37(2.4)$ & $7.87(2.2)$ & $7.88(2.1)$ & $7.22(1.8)$ \\
\hline $\mathrm{T}_{9}:$ Recommended NK + $75 \%$ Recommended P +PSF & $20.39(6.1)$ & $19.03(5.9)$ & $21.06(5.7)$ & $12.47(3.2)$ & $9.6(2.4)$ & $8.18(2.2)$ & $7.93(2.2)$ & $7.60(1.9)$ \\
\hline $\mathrm{T}_{10}:$ Recommended NPK & $27.84(7.7)$ & $23.50(5.8)$ & $27.50(6.2)$ & $17.53(3.9)$ & $9.23(2.8)$ & $8.28(2.4)$ & $8.30(1.9)$ & $8.30(1.9)$ \\
\hline $\mathrm{T}_{11}:$ Recommended NPK + PSB & $26.53(7.6)$ & $21.12(5.7)$ & $24.20(6.6)$ & $15.53(3.7)$ & $9.3(2.8)$ & $8.32(2.2)$ & $8.83(2.4)$ & $9.00(2.2)$ \\
\hline $\mathrm{T}_{12}$ : Recommended NPK + PSF & $24.17(7.1)$ & $21.70(6.0)$ & $23.50(6.2)$ & $14.71(3.5)$ & $10.28(2.7)$ & $9.6(2.3)$ & $8.90(2.3)$ & $9.23(2.2)$ \\
\hline S. Em. \pm & 0.85 & 0.84 & 0.83 & 0.38 & 0.32 & 0.29 & 0.34 & 0.35 \\
\hline C.D. $(p=0.05)$ & 2.50 & 2.46 & 2.44 & 1.11 & 0.94 & 0.86 & 0.98 & 1.02 \\
\hline
\end{tabular}

Note: FYM is common to all the treatments PSB: Phosphorus Solubilizing Bacteria PSF: Phosphorus Solubilizing Fungi DAP - Days after planting. Figures in the parenthesis indicate the per cent contribution to the total P pool.

Higher values of Ca: $\mathrm{P}$ fractions were recorded in treatments received $\mathrm{P}$ levels with $\mathrm{P}$ solubilizers seedling treatment compared to the application of only $\mathrm{P}$ levels. Highest values of $\mathrm{Ca}-\mathrm{P}$ fraction was recorded in treatment that received RDF with PSF seedling treatment (10.28, 9.6, 8.90 and 9.23 mg kg-1 at 30, 60, 90 DAP and at harvest, respectively) followed by treatment that received RDF with PSB seedling treatment. Compared to other treatments (Table 3). The buildup of Ca-P compared to control in the $\mathrm{P}$ applied soils as $\mathrm{P}$ fertilizer alone or with $\mathrm{P}$ solubilizers was also observed by Mathan and Joseph (1998) ${ }^{[9]}$.

Highest values of organic: $\mathrm{P}$ fraction was recorded in treatment that received recommended NPK (182.54, 238.10, 264.62 and $290.42 \mathrm{mg} \mathrm{kg}-1$ at 30, 60, 90 DAP and at harvest, respectively) followed by treatment $\mathrm{T} 7$. Lowest value of organic - P fraction in soil was recorded in treatment that received recommended NK with PSF seedling treatment. An increase in organic $\mathrm{P}$ in the soil was observed with application of P fertilizers (Ranjit, 2005) ${ }^{[12]}$. This is due to excess $\mathrm{P}$ may be inhibited phosphorylase activity and consequently suppressed the mineralization processes and favored a buildup of organic P. Soil microorganisms also play an important role in organic $\mathrm{P}$ transformations in soil through excretion of enzymes like phosphatase and dehydrogenase. Phosphatase catalyses the hydrolysis of esters and anhydrides of phosphoric acid and thus its activity indicates the mineralization potential of organic $\mathrm{P}$ in soils (Dick and Tabatabai, 1993) ${ }^{[4]}$.

Higher values of total: $P$ fractions were recorded in treatments that received the application of only $\mathrm{P}$ levels compared to the application of $\mathrm{P}$ levels with $\mathrm{P}$ solubilizer seedling treatment. Highest values of total - $\mathrm{P}$ fraction was recorded in treatment that received Recommended NPK (363.61, 405.39, 372.84 and $448.02 \mathrm{mg} \mathrm{kg}-1$ at 30, 60, 90 DAP and at harvest, respectively) followed by treatment that received recommended NPK with PSB seedling treatment. Lower value of total - $\mathrm{P}$ fraction in soil was recorded in treatment that received recommended NK with PSF seedling treatment(Table 4). The total - $\mathrm{P}$ in all the treatments increased with crop growth except in no $\mathrm{P}$ applied with or without PSB. There was significant increase in total $-\mathrm{P}$ in the soil with application of $\mathrm{P}$ fertilizers. These results corroborates with the findings of Sheela (2006) ${ }^{[14]}$ and Ranjit $(2005)^{[12]}$.

Table 4: Effect of $\mathrm{P}$ levels and $\mathrm{P}$ solubilizers seedling treatment on organic $\mathrm{P}$ and total $\mathrm{P}$ fractions in soil at different intervals in paddy

\begin{tabular}{|c|c|c|c|c|c|c|c|c|}
\hline \multirow{3}{*}{ Treatments } & \multicolumn{4}{|c|}{ Organic: $\mathbf{P}$} & \multicolumn{4}{|c|}{ Total: P } \\
\hline & \multicolumn{8}{|c|}{$\left(\mathrm{mg} \mathrm{kg}^{-1}\right)$} \\
\hline & 30 DAP & 60 DAP & 90 DAP & Harvest & 30 DAP & 60 DAP & 90 DAP & Harve \\
\hline NK only & \multicolumn{2}{|c|}{$182.54(55.6) 210.05(64.9$} & $208.70(64.9$ & $190.29(65.3)$ & 328.59 & 323.57 & 321.74 & 291.56 \\
\hline nended NK + PSB & \multicolumn{4}{|c|}{$182.37(57.2) 213.24(68.1) 188.42(64.5) 194.32(67.6$} & 318.94 & 312.90 & 292.13 & 287.61 \\
\hline $\mathrm{T}_{3}: \mathrm{Re}$ & \multicolumn{4}{|c|}{$181.77(57.3) 198.43(66.8) 181.10(64.3) \mid 185.03(66.1)$} & & & & \\
\hline $\mathrm{T}_{4}$ : Recommend & \multicolumn{4}{|c|}{$165.58(48.2) 215.88(61.8) 255.26(66.0) 276.62(68.5)$} & & 349.05 & 386.66 & \\
\hline$T_{5}:$ Recommended NK + $50 \%$ Recommended P + PSB & \multicolumn{4}{|c|}{$3158.90(49.7) 197.77(61.2) 232.47(65.3) 253.56(68.7$} & 319.46 & 323.36 & 355.92 & 369.25 \\
\hline 6: Recommended NK + 50\% Recommended P + PSF & \multicolumn{4}{|c|}{$162.08(51.0) 201.68(62.4) 228.61(65.0) 252.18$ (69.0 } & 317.75 & 323.10 & 351.71 & 365.74 \\
\hline $\mathrm{T}_{7}$ : Recommended NK + $75 \%$ Recommended P & \multicolumn{4}{|c|}{$151.7(43.6) 221.40(59.4) 250.77(62.5) 283.29(67.2)$} & 347.93 & 372.73 & 400.99 & 421.56 \\
\hline $\mathrm{T}_{8}:$ Recommended NK + $75 \%$ Recol & \multicolumn{4}{|c|}{$154.20(45.7) 195.1(58.2) 233$} & 337.65 & 335.10 & 52 & .86 \\
\hline T9: $\operatorname{Rec}$ & \multicolumn{4}{|c|}{$149.61(45.1) 183.5(56.8)$} & & 323.29 & 363.41 & 394.95 \\
\hline $\mathrm{T}_{10}: \operatorname{Rec}$ & \multicolumn{4}{|c|}{$144.81(39.8) 238.10(58.7) 264.62(61.7) 290.42(64.8)$} & 363.61 & 405.39 & 428.96 & 448.02 \\
\hline $\mathrm{T}_{11}:$ Recommended NPK $+\mathrm{P}_{4}$ & \multicolumn{4}{|c|}{$142.59(41.1) 220.92(59.3) 227.05(59.8) 273.41(64.3)$} & 347.34 & 372.84 & 379.79 & 425.20 \\
\hline $\mathrm{T}_{12}:$ Recomme & \multicolumn{4}{|c|}{$140.46(41.4) 208.45(57.9)$} & 339.23 & 360.19 & 381.48 & 422.06 \\
\hline & & & & & 7.21 & 8.22 & 9.59 & 9.72 \\
\hline C.D. $(p=0.05)$ & 22.10 & 27.82 & 28.73 & 26.94 & 21.15 & 24.10 & 28.14 & 28.51 \\
\hline
\end{tabular}

Note: FYM is common to all the treatments PSB: Phosphorus Solubilizing Bacteria PSF: Phosphorus Solubilizing Fungi

\section{Conclusion}

The study indicated a buildup of high $\mathrm{P}$ in the soils under paddy which can be exploited using $\mathrm{P}$ solubilizer. Though the higher yield of paddy was obtained with application of $100 \%$ $\mathrm{RDF}+\mathrm{P}$ solubilizers it was found on par with the application of $\mathrm{RD}-\mathrm{NK}+75 \% \mathrm{RDP}+\mathrm{P}$ solubilizers. Hence, application 
of RDF with $\mathrm{P}$ solubilizers can be used for profitable paddy cultivation under high phosphorus.

\section{References}

1. Beever RE, Burns DJW. Phosphorus uptake, storage and utilization by fungi. Adv. Bot. Res. 1981; 8:127-219.

2. Chang SC, Jackson ML. Fractionation of soil phosphorus. Soil Sci. Soc. Am. J. 1957; 84:133-144.

3. Chilean Ultisol. Soil Use Manage. 27, 221-228.

4. Dick WA, Tabatabai MA. Significance and potential uses of soil enzymes. In: Metting FB (Ed.). Soil Microbial Ecology: Appl. Agric. Environ. Manage. Marcel Dekker, New York, 1993, 95-127.

5. Gerretsen FC, The influence of microorganisms on the phosphate intake by the plant. Pl. Soil. 1948; 1:51-81.

6. GOROJI PT. Transformation of phosphorus in a Vertisol in sunflower - jowar cropping sequence. Ph. D. Thesis, Univ. of Agric. Sci., Dharwad, 2000.

7. Jackson ML. Soil Chemical Analysis. Prentice Hall Pvt. Ltd., New Delhi, 1967.

8. Kang SC, Hat CG, Lee TG, Maheshwari DK. Solubilization of insoluble inorganic phosphates by a soil-inhabiting fungus Fomitopsis sp. PS 102. Curr. Sci. 2002; 82:439-442.

9. Mathan CK, Joseph B. Influence of different fertilizer sources on phosphorus dynamics. J. Indian Soc. Soil Sci. 1998; 46(4):686-688.

10. Park M, Singvilay O, Shin W, Kim E, Chung J, Tongmin SA. Effects of long-term compost and fertilizer application on soil phosphorus status under paddy cropping system. Commun. Soil Sci. Pl. Anal. 2004; 1112:1635-1644.

11. Peterson GW, Corey RB. A modified Chang and Jackson procedure for routine fraction of inorganic soil phosphates. Soil Sci. Soc. Am. Proc. 1966; 30:563-564.

12. Ranjit R. Response of groundnut genotypes to lime and phosphorus levels in coastal alluvial soil of north Karnataka. M. Sc. Thesis submitted to the Univ. Agric. Sci., Dharwad, 2005.

13. Rao S. Fractionation of residual $\mathrm{P}$ compounds in black and red soils. J. Indian Soc. Soil Sci. 1972; 20:323-326.

14. Sheela BS. Dynamics of phosphorus in acid soils of North Karnataka. M. Sc. (Agri.) Thesis, Univ. Agric. Sci., Dharwad, 2006.

15. Singaram $P$, Kothandaraman GV. Direct, residual and cumulative effects of phosphatic fertilizers as yield attribute on yield of finger millet, maize and black gram grown in cropping sequence. Fert. News. 1991; 36(8):2127.

16. Singaram $P$, kothandaraman GV. Residual effect of different $\mathrm{P}$ fertilizers on available $\mathrm{P}$ of soil in the cropping sequence. J Indian Soc. Soil Sci. 1992; 40:213215.

17. Singaram $P$, Kothandaraman GV. Effect of $P$ sources on phosphorus uptake by finger millet and changes in inorganic P fractions. J. Indian Soc. Soil Sci. 1993; 41(3):588-590.

18. Singh S, singh SB. Effect of water logging and organic matter in inorganic $\mathrm{P}$ fractions of soils. J Indian Soc. Soil Sci. 1976; 24(1):88-90.

19. Yuan TL, Robertson WK, Neller JR. Form of newly fixed phosphorus in three acid soils. Soil Sci. Soc. Am. Proc. 1960; 24:447-450. 